\title{
Tracing the Origins of the Netherlands' Tax Treaty Network
}

\author{
Maikel Evers LL.M. ${ }^{1}$
}

\begin{abstract}
This contribution identifies the main determinants and key persons that constituted the tax treaty policy of the Netherlands. This policy is rooted in the political chess games in $19^{\text {th }}$ century mainland Europe. In this century, European states gained experience in negotiating trade and tax agreements. Not only were the

Germans experts in divide and rule strategies; they also developed instruments that form the core of contemporary tax treaty law. Dutch tax treaty policy blossomed when the Netherlands opened tax treaty negotiations with Germany. Negotiations that followed an erratic course, making their mark on the notorious tax treaty policy of the Dutch. The Dutch legislator refined the tax system to support a fruitful tax treaty policy, focusing on becoming an intermediary state for international investment. However, the firm position of the Dutch on bank secrecy had thrown a spanner in the works. Finally, the erratic course of these early tax treaty negotiations inspired the League of Nations tax committees through some of their key members.
\end{abstract}

\section{Introduction}

Over the last century, the Netherlands has earned a reputation in the international tax arena. The small country traditionally has a relatively extensive tax treaty network. In many investment structures, the Netherlands turn up as the linking pin between larger economies. In this article I will trace the roots of the Dutch tax treaty network, all the way down to the roots of the contemporary international tax system. Contrary to the claim of the OECD in its report Addressing Base Erosion and Profit Shifting ${ }^{2}$ (BEPS Report), this system was conceived long time before the League of Nations entered the tax arena. Building upon literature and on examination of governmental records, I will identify the key factors that had an impact on the autonomy of the Netherlands to develop its tax treaty policy. In particular this contribution concentrates on the development of tax treaty policy in the Netherlands up to WWII. The relation between the Netherlands and neighbouring Germany played a big part in this development.

This contribution recounts the impact of the German-Dutch relation in two parts. In the first part, I will identify some of the relevant political and economic circumstances that form the background against which the Netherlands developed its treaty policy. Even though treaties on international trade, investment and taxation are old as the hills, ${ }^{3}$ I choose the $19^{\text {th }}$ century as my point of departure. ${ }^{4}$ During this period, the

\footnotetext{
${ }^{1}$ Maikel Evers (evers@law.eur.nl) is member of the staff of the Erasmus School of Law (Erasmus University Rotterdam) and the Netherlands Ministry of Finance. This contribution is based on research that is part of the research program Tax Autonomy and its Boundaries. Some of the documents that have been used for the analysis in this contribution are published on etld.blogspot.com, the weblog of the Erasmus Tax Law Department.

${ }^{2}$ OESO, Addressing Base Erosion and Profit Shifting, Paris: OECD 2013, p. 5, 34-35.

${ }^{3}$ Weber-Fas refers to the 'Dictum' of Spitaler that is commonly found in international tax law literature: 'Double taxation is age-old. It is as old as the oldest tax', Armin Spitaler, Das Doppelbesteuerungsproblem bei den Direkten Steueren, Keulen: Verlag Dr. Otto Schmidt 1936. I however agree with the nuance pointed out by Weber-Fas that both the modern concept of 'state' and the contemporary direct tax systems are relatively young from a political historical perspective; Rudolf Weber-Fas, Staatsverträge im Internationalen Steuerrecht: zur Rechtsnatur, Geschichte und Funktion der Deutschen Doppelbesteuerungsabkommen, Tübingen: J.C.B. Mohr 1982, p. 2-3.

${ }^{4}$ Similarly, in other recent publications 19th century Europe is seen as the nursery for the contemporary tax treaty network; see for example Hildegard Hemetsberger-Koller \& Evelyn Kolm, 'Globalisation and International Taxation in the XIXth Century: Double Taxation Agreements with Special Reference to the "State of the Fund" Principle', European Economic History, Vol. 35, No. 1, pp. 112-113; Sunita Jogarajan, 'Prelude to the International Tax Treaty Network: 1815-1914 Early Tax treaties and the Conditions for Action', Oxford Journal of Legal Studies, Vol.31, 2004-4, p. 679-707; Johann Hattingh, 'The Origins of Model Tax Conventions: An Overview
} 
Netherlands concluded its first treaties in the field of taxation. This was also the century in which the foundations were laid for the first comprehensive treaties for the avoidance of double taxation. As I will set out in this first part, the currently heavily debated international tax system was developed as part of the German integration process in the late $19^{\text {th }}$ century. The second, longer part of this contribution covers the period of 1904 to 1940. Not without striking a blow, the Netherlands negotiated its first comprehensive tax treaty in this period: the treaty for the avoidance of double taxation with Germany.

\section{PART I: POlitical AND ECONOMIC BACKGROUND 1814-1903}

\subsection{Introduction}

The conception of tax treaty policy of the Netherlands and other European countries occurred against the backdrop of the economic and political turmoil of the $19^{\text {th }}$ century. Often the term 'Concert of Europe' is used when describing international politics in $19^{\text {th }}$ century Europe. ${ }^{5}$ The relationships between European nations were however far from harmonious. Many economic and armed conflicts where fought by big, European nations, affecting political and economic development in smaller, nearby countries as well. As I will point out in the following sections, the first modern tax treaties are rooted in these developments. In section 1.2 hereafter, I will first focus on the developments in the Benelux countries. In section 1.3, I will a give short overview of the German integration process in the $19^{\text {th }}$ century.

\subsection{The South: Combat and Competition}

In 1845 the Netherlands and Belgium concluded an agreement on the mutual assistance in tax matters which is still in force today. ${ }^{6}$ This agreement was part of a series of treaties that the Netherlands concluded with Belgium. The treaties formalized the young inter-state relations and can be seen as a culmination of the struggle for independence of the Belgians. The Belgian-Dutch treaties were based on recent treaties between Belgium and France. Northern France was economically dependent on Belgium. Also, France wanted to avoid Belgium moving closer to the German states. Belgium came out of its struggle for independence from the Netherlands successfully and soon developed into a relatively flourishing state. For the Netherlands, Belgium was an important trading partner, as the two countries' economies were still heavily intertwined. On the other hand, Belgium was an important competitor of the Netherlands in the trade relation with the German states. The Germans successfully cashed in on this.

\subsubsection{Battle for Belgium}

Let's take a closer look at the relation between the Netherlands and Belgium. The Belgian revolt against the Netherlands originated a period a few decades earlier, when Napoleon was defeated. At the Congress of Vienna of 1814 and 1815, the major European powers Britain, Prussia, Russia and Austria came to a reconfiguration of state borders in Europe and appointed new heads of state. As part of this settlement, the major powers decided that a new Northern-European state had to be created to avoid new northern

\footnotetext{
Century German Tax Treaties and Laws concerned with the Avoidance of Double Taxation', in: John Tiley (ed), Studies in the History of Tax Law Vol. 5, Oxford: Hart Publishing (forthcoming).

${ }^{5}$ See for example John Lowe, The Concert of Europe: International Relations, 1814-70, London: Hodder \& Stoughton 1990; John M. Sherwig, 'Lord Grenville's Plan for a Concert of Europe, 1797-99', The Journal of Modern History, Vol. 34 (1962), No. 3, pp. 284-293; Georges-Henri Soutou, 'Was There a European Order in the Twentieth Century? From the Concert of Europe to the End of the Cold War', Contemporary European History, Vol. 9 (2ooo), No. 3, pp. 329-353.

${ }^{6}$ Overeenkomst inzake de wisseling van renvooien tussen de Nederlandsche en Belgische administratie of 24 May 1845 , re-publiced in Government Gazette No. 1997, 232.
} 
expansion by France. They created the Kingdom of the Netherlands as a medium-sized state in the territory of the present day Benelux. The House of Orange-Nassau was asked to deliver a head of state and in 1815 Frederick William I of Orange was appointed sovereign of the Kingdom of the Netherlands. ${ }^{7}$ The Dutch rule in Belgium lasted only a short time. In a European wave of revolutions that were in fact protests against the Vienna settlement, ${ }^{8}$ the Provisional Government of Belgium proclaimed independence in 1830 . The initial Belgian proposal to appoint the Duke of Nemour, son of the French king, as the first King of the Belgians led to heavy criticism by other European countries. ${ }^{9}$ Eventually the German Leopold of SaxeCoburg and Gotha was chosen as the head of state of independent Belgium. After years of fierce armed conflict, largely supported by France, the Netherlands finally recognized the independence of Belgium in 1839 .

The French support of the Belgians can easily be explained. As Northern France was economically dependent on the relatively prosperous Belgium, the French wanted to obtain more influence in Belgium than they had with Belgium under Dutch rule. Also, an alternative French proposal to divide Belgium was not embraced by the other European nations. ${ }^{10}$

\subsubsection{Interdependence and Negotiating Tactics}

France envisaged strengthening its economic ties with Belgium. France therefore pushed for various treaties in the field of trade, economy and taxes. By strengthening the Franco-Belgian ties, France hoped that the Belgians would not join the German customs union, the Zollverein (see below). ${ }^{11}$ When Belgium in 1844 expressed the intention to enter into a customs union with the German nations, the French King even threatened with war, to which Belgium renounced its intention. ${ }^{12}$

Like France, the Netherlands also approached the newly independent Belgium. Forced by its poor economic condition, ${ }^{13}$ the Netherlands could relatively easily step over its resentments. The Netherlands soon agreed on trade and tax treaties with Belgium which followed the Franco-Belgian treaties. One of the agreements was the 1845 Mutual Assistance Agreement mentioned above.

The Netherlands was heavily dependent on its trade with the neighbouring countries. The Dutch also feared the Belgian rapprochement with the German Zollverein. Increased cooperation between the Germans and the Belgians threatened the Dutch competitiveness in Northern European trade. ${ }^{14}$ The Dutch relationship with the Zollverein was in fact difficult. An initial agreement between the Netherlands and the Zollverein states was signed in 1839 , but was terminated in 1849 by the Germans. ${ }^{15}$ The Dutch were forced to re-negotiate with the Germans, but faced heavy competition from the Belgians, who were negotiating on trade and tax agreements with the Germans as well. For the experienced Prussian diplomats, these were profitable circumstances. The Prussians could easily play the Netherlands and Belgians off against each

\footnotetext{
${ }^{7}$ Implementation of a Protocol signed in London on 21 June 1814, proposed by William Frederic himself. At that time, William was still the sovereign of the German principality of Nassau-Dietz. With the acquisition of sovereignty over Luxemburg he renounced his claims on Nassau-Dietz, see Netherlands Government Gazette 1816, 123.

${ }^{8}$ Roy Bridge \& Roger Bullen, The Great Powers and the European States System 1814-1914, Harlow: Pearson Education 2005, p. 86.

${ }^{9}$ See C. Smit, De conferentie van Londen - Het vredesverdrag tussen Nederland en België van 19 April 1839, Leiden: E.J. Brill 1949, pp. 110-127.

${ }^{10}$ Proposal of the French diplomat Talleyrand. Western Flanders would become a British protectorate, while Antwerp would become an independent city State. The other areas would be divided between France, Prussia and Germany.

${ }^{11}$ Belgium had already concluded a trade agreement with the Zollverein in 1844.

${ }^{12}$ Ernest Mahaim, 'La politique commerciale de la Belgique', in: Gustav Schmoller (red.), Die Handelspolitik Nordamerikas, Italiens, Österreichs, Belgiens, der Niederlande, Dänemarks, Schwedens und Norwegens, Russlands und der Schweiz in den letzten Jahrzehnten sowie die deutsche Handelsstatistik von 1880 bis 1890, Leipzig: Verlag von Dunder \& Humblot 1892, p. 205.

${ }^{13}$ The Belgian revolt had put a heavy financial burden on budget of the Netherlands Government, resulting in high government debt and interest costs, see Ernst H. Kossmann, The Low Countries: 1780-1940, Oxford: Clarendon Press 1978, p. 182.

${ }^{14}$ William O. Henderson, The Zollverein, Cambridge: Cambridge University Press 1938, pp. 167-171.

${ }^{15}$ Treaty of 21 January 1839. The treaty, amongst other things, provided for a beneficial treatment of Dutch sugar exports. The German sugar industry protested and forced the German authorities to terminate the treaty.
} 
other, ${ }^{16}$ with the two small countries ending up with a far worse deal than they had hoped for. In this situation, the Netherlands had little choice other than to accept major concessions in the negotiations on a new treaty with the Zollverein. In 1851 a new treaty of commerce and navigation with Prussia and other States of the German Customs Union was concluded. ${ }^{17}$

In other words, the Netherlands and Belgium were pawns in the battle for the throne by the European super powers of the $19^{\text {th }}$ century. These circumstances had significant impact on the Dutch autonomy to conclude treaties related to trade and taxation.

\subsection{The East: German Integration}

After focussing on the developments south of the Netherlands, let's shift the focus to the developments in the east. In the course of the $19^{\text {th }}$ century, the dominance of German-speaking Europe increased as a result of impressive economic and political integration. Economic analysis of the German integration process also uncovers sophisticated negotiation strategies, which have recurred throughout political history. Against the backdrop of conflicts and cooperation the German nations developed legal instruments that today are core elements of international and European taxation.

\subsubsection{German Unification}

In the early 19th century, German-speaking Europe was a patchwork consisting of small and larger Kingdoms, principalities and free cities. At the Congress of Vienna it was decided not to create a united German-speaking nation. A strong, united Germany would be a threat to other European states. ${ }^{18}$ The only possible association at that time was a loose confederation: the German Confederation.

Integration within the German Confederation went slow and initially existed merely in economic terms. The most important instrument for economic collaboration was the already mentioned German Zollverein, which was founded in $1834 .{ }^{19}$ Within this union it was possible to trade goods across border free of tolls or with reduced tariffs. In the traditional academic literature, the Zollverein was seen as a deliberate step of Prussia towards political unification of Germany. ${ }^{20}$ More recent analysis of this customs union has shown that the success of the Zollverein was constructed quite differently. Economic research uncovered that the principal motive for German states to join the Zollverein were the economic benefits of the union rather than a political motive. ${ }^{21}$ The economic benefit as such does however not give a full explanation for the expansion and the success of the union. An important factor on the formation process of the union turns out to be the so-called coalition externalities: the effects of coalition on parties that are outside the coalition. Cooperation within the union changes the playing field in the region and changes competition, creating an incentive for states outside the coalition to join sooner than later. According to Ploeckl, this

\footnotetext{
${ }^{16}$ See for example the analysis in Tijdschrift voor Geschiedenis 1927, p. 416 of documents from the Netherlands Government Archives printed in Nicolaas W. Posthumus, De Nederlandsche Handelspolitiek. Documenten betreffende de Buitenlandsche Handelspolitiek van Nederland, in de Negentiende eeuw, Part V and XVI, The Hague: Martinus Nijhoff 1927.

${ }^{17}$ Verdrag van Handel en Scheepvaart met Pruisen en de verdere Staten van het Duitsche Tolverbond, Treaty of ${ }_{31}$ December 1851 . In the Explanatory Note to the treaty, the Netherlands government provided insight into the painful genesis of the treaty, Kamerstukken II 1851/52 (no number), pp. 619-623. 'Kamerstukken II' are the official title of the documents of the Lower House (Second Chamber) of the Netherlands Parliament. Kamerstukken can be consulted in Dutch via statengeneraaldigitaal.nl and overheid.nl.

${ }^{18}$ See on the German unification process Frank B. Tipton, A History of Modern Germany since 1815, London: Continuum International Publishing Group 2003, pp. 25-89.

${ }^{19}$ Ploeckl describes the origins and the economic effects of the Zollverein in: Florian T. Ploeckl, The Zollverein: Formation and impact of a Customs Union, Michigan: Proquest UMI Dissertation Publishing 2011.

${ }^{20}$ Heinrich von Treitschke, 'Die Anfänge des deutschen Zollvereins', Preußische Jahrbücher 1872, pp. 397-466.

${ }^{21}$ Economic benefits of a union consists of, amongst other, economy of scale and a reduced administrative burden, see Rolf H. Dumke, The Political Economy of German Economic Unification: Tariffs, Trade, and Politics of the Zollverein Era, (diss. University of Wisconsin) Madison: 1976.
} 
explains how the Zollverein has always succeeded in negotiation very favourable terms with acceding parties. ${ }^{22}$

German economic integration was not without considerable struggle. The power struggle between the dominant parties Prussia and Austria led to war. Consequently, the German Confederation fell apart in 1866. Austria formed a dual monarchy with Hungary, while Prussia along with other states north of the river Mainz entered into a new cooperation: the North German Confederation. This new confederation was redeemed from the power struggle between two dominant parties, clearing the roads for further integration: economically, as well as politically. ${ }^{23}$

\subsubsection{The First Double Tax Arrangements}

For economic development and industrialization to accelerate, the German states introduced many legal measures to reduce obstacles for inter-state trade and investment. One of the cornerstones was the right of free movement and establishment, guaranteed by the Federation's constitution. Entitled to establish federal laws to guarantee this constitutional right, the German federal parliament soon introduced pioneering pieces of legislation, such as the Gesetz über die Freizügigkeit (Freedom of Establishment Act) of November 1, 1867. Increase in cross border trade and investment combined with the separate income and wealth tax system of the German states also resulted in increase of double taxation. ${ }^{24}$ Double taxation hampered the constitutional freedoms. Prompted by petitions from influential landowners and backed by Count de Bethusy-Huc, Member of the Reichstag of the North German Federation, started discussions on finding solutions to reduce double taxation. At first, it appeared to be difficult to find a multilateral solution. On April 16, 1869 Prussia and Saxony concluded a tax treaty for the avoidance of double taxation. This was a bilateral treaty, but article 8 of the bilateral treaty offered other states of the North German Confederation the possibility to join. ${ }^{25}$ This bilateral treaty was merely meant as a provisional solution, as the German parliamentarians meanwhile kept on working on a multilateral arrangement. Under political pressure of influential noblemen, the Reichstag agreed upon a Reichsgesetz on the avoidance of double taxation was introduced on 13 May 1870 (hereafter: the 1870 Law). ${ }^{26}$ This federal law, applicable in the entire North German Confederation, largely followed the structure and principles of the 1869 treaty.

On January 18, 1871, William of Prussia proclaimed the German Empire, a political union dominated by Prussia. ${ }^{27}$ The German Empire soon sought rapprochement with Austria-Hungary, forming an alliance. Later also Italy joined this alliance. The motives of Germany to engage in close cooperation with these countries were clear. First, economic cooperation within the alliance should attribute to economic welfare of the countries. Secondly, and for the politicians perhaps more importantly, it would strengthen the position of German speaking Europe in the economic wars with France. Although giving up part of legislative autonomy in the field of trade and taxes by signing treaties and coordinating policy, the members of the alliance increased autonomy in their relations to France as a result as an increase in relative economic power.

\footnotetext{
${ }^{22}$ See Ploeckl, note 19, en Florian T. Ploeckl, 'The Zollverein and the Formation of a Customs Union', discussion Papers in Economic and Social History No. 84, August 2010, via ideas.repec.org.

${ }^{23}$ The German empire under Bismarck focused on stability within Kleindeutschland, Smaller Germany, rather than trying to establish a greater Germany including multi-ethnic Austria, see Jas Grenville, Europe Reshaped: 1848-1878, $2^{\text {nd }}$ edition, London: Blackwell 2000 , pp. $264-287$.

${ }^{24}$ Prussia already had a long tradition of income taxes, while other countries including England only had known temporary income taxes in war time.

${ }^{25}$ Also see Johannes Kippenberg, 'Ältestes DBA: Das DBA Preußen-Sachsen von 1869', IStR 24/2006, pp. II-III.

${ }^{26}$ Th. Clauss, 'Das Reichsgesetz vom 13. Mai 1870 wegen Beseitigung der Doppelbesteuerung unter Vergleichender Berücksichtigung des Schweizer Bundesrechtes', Finanzarchiv, No. 1888/1, pp. 138-197.

${ }^{27}$ At the time, the Prussia was in war with France. One of the triggers for the start of this war was the French opposition to the proposed King of Spain: the German Leopold von Hohenzollern. Emperor Napoleon III of France feared an increase of Prussian influence in European politics and the encirclement of France.
} 
As part of a series of treaties on trade and tariffs, ${ }^{28}$ the members of the alliance also introduced measures for the avoidance of double taxation. The Prussian-Saxon treaty served as inspiration for what by many tax scholars is still - incorrectly - considered as the first full DTA: the tax treaty between Prussia and AustriaHungary of June $21,1899 .{ }^{29}$

The treaties of 1869 and 1899 and the 1870 Law had laid the foundation of the tax treaties we still know today. The 'schedular structure' ${ }^{30}$ of the OECD and UN Model Conventions were already present in the 1869 treaty, distinguishing between various types of income. This structure proved to be a very efficient system to allocate taxing rights even though the tax systems of the $19^{\text {th }}$ century German states diverted to great extent. ${ }^{31}$ The suitability of the structure of the 1870 Law was underlined by the fact that the arrangement remained in effect for three decades. ${ }^{32}$ These first double tax arrangements also introduced concepts that would later be important components of international tax law, such as the concept of permanent establishment, in German Betriebsstätte. ${ }^{33}$ Moreover, the 1869 and 1870 arrangements made a significant imprint on the composition of the tax systems of the states concerned. In subsequent tax reforms, many German states introduced income tax systems that perfectly matched with the taxing rights attributed to these states in the 1870 Law. ${ }^{34}$ This means that not only the German integration process has produced the legal instruments that shaped the contemporary worldwide tax treaty network, but also that the composition of the tax systems of many states around the world are shaped within the boundaries imposed by the structure of tax treaties. Finally, this also means that the OECD BEPS Report inaccurately refers to the 1920's as the era in which many of the basic principles of the international tax system were developed. ${ }^{35}$

\footnotetext{
${ }^{28}$ For a short period, the Netherlands government thought that Germany and Austria-Hungary would approach the Netherlands as well. This turned out not to be the case. See letter of the Netherlands Minister of Foreign Affairs to the Netherlands Council of Ministers of 22 May 1891 , second division, No. 5288/91, published in: J. Woltring, Bescheiden betreffende de Buitenlandse Politiek van Nederland - Tweede Periode 1871-1989, Part V, The Hague: Martinus Nijhoff 1970, pp. 111-114.

${ }^{29}$ See, for example, John G. Herndon, Relief from International Income Taxation: The Development of International Reciprocity for the Prevention of Double Income Taxation, Chicago: Callaghan \& Co 1932, as referred to by Stef van Weeghel, The Improper Use of Tax Treaties: With Particular Reference to the Netherlands and the United States, The Hague: Kluwer Law International 1998, p. 27., but also more recently: Michael Kobetsky, International Taxation of Permanent Establishments: Principles and Policy, Cambridge: Cambridge University Press 2011, p. 109.

${ }^{30}$ Peter Harris, Income Tax in Common Law Jurisdictions: Volume 1, From the Origins to 1820, Cambridge: Cambridge University Press 2006, p. 19.

${ }^{31}$ At the time, most German states relied heavily on impersonal, objective taxes, subjecting specific types of assets and incomes to specific regimes. Double taxation therefore occurred in an economic sense, more than in the sense of juridical double taxation of a person's income under two similar tax systems of two or more different states. The system of the 1870 Law is based on the allocation of taxing rights, which did not require any adjustment to the tax systems of the states concerned. As long as these states refrained from taxation when the Law so prescribed, double taxation was in principle avoided. Whether or the state that has the taxing right under the 1870 Law in practice exercises this right was in principle irrelevant.

${ }^{32}$ The 1870 Law was amended in 1909.

${ }^{33}$ This term first occurred in company law around 1845 and was century imported into tax law in the second half of the $19^{\text {th }}$. In the context of international tax law, the term 'Betriebsstätte' was first used in the 1899 tax treaty between Prussia and Austria-Hungary, J.D. Kolck, Der Betriebsstättenbegriff im Nationalen und im Internationalen Stuerrecht, (diss) University of Münster 1974, pp. 9-10. However, the tax law concept of Betriebstätte was already developed by in German tax law, as uncovered by Hattingh. In interpreting the similar terms 'Betriebe eines stehenden Gewerbes' in the 1869 treaty and the 'Betriebe eines Gewerbe' in the 1870 Law, various German courts developed a framework to attribute profits to the various states in which an enterprise was active. A ruling issued by the Saxon Ministry of Finance prescribed the separate entity approach already in 1885 . See Hattingh, supra note 4 for translations and analysis of relevant German case law and governmental rulings.

${ }^{34}$ Residents were in principle subject to taxation on their annual net income from capital, immovable property, trade and industry and employment income. Non-resident's income from landed property situated in Prussia was subject to Prussian tax, as well as their non-residents business income arising in that state. The Prussian tax system was copied by other German states, by 1914, 25 of the 28 of the German states applied this system; Edwin R. A. Seligman, The Income Tax: A Study of the History, Theory and Practice of Income Taxation at Home and Abroad, $2{ }^{\text {nd }}$ ed, New York: Macmillan 1914, pp. 259-261.

${ }^{35}$ Supra note 2.
} 


\subsection{Introduction}

Shortly after the conclusion of the tax treaty between Prussia and Austria-Hungary, the process of tax treaty negotiations came off the ground in the Netherlands. In the sections below I will describe this process. In the following subparagraphs I will uncover that, contrary to common academic conception, the first Dutch tax treaties are not founded on the findings of the League of Nations Committees, nor the 1928 Model Conventions published by the League of Nations Commissions. Instead, in the Netherlands the efforts of a couple of key persons sparked the international tax policy of the Netherlands.

\subsection{Launch of the Dutch Tax Treaty Network}

\subsubsection{Considerations}

At the end of the 19th century, the Dutch legislator decided to reform the tax system. After long discussions, the system for excises was modified and a wealth tax was introduced. A general income tax covering also individuals had yet to be introduced. ${ }^{36}$ As many countries levied a wealth tax at that time, the risk of international double taxation occurred. The first steps of the Dutch Ministry of Finance for introducing measures for the avoidance of double taxation were not inspired by a conceptual notion that double taxation should be relieved. Instead, archival research shows that the reason lies in a complaint of a double resident avant la lettre, who was subject to double wealth tax. Count William Bentinck und Waldeck Limpurg had possessions in both the Netherlands (estate Middachten to Rheden) as in Gaildorf, in the former Kingdom of Württemberg (in the current German State of Baden-Württemberg). On behalf of Count Bentinck, the German ambassador in The Hague ${ }^{37}$ wrote a letter to Robert Melvil, Baron of Lynden, the Netherlands Minister of Foreign Affairs, in 1904. The Minister of Foreign Affairs requested the Minister of Finance to seek a solution to this problem of double taxation. ${ }^{38}$ In response to this request, the Minister of Finance indicated he was prepared to find a solution by initiating negotiations with 'the German (or the Würtemberger) Government'. ${ }^{39}$ However, he preferred to 'have a principle based discussion of the matter with Parliament' before approaching the Germans. ${ }^{40}$

\subsubsection{Modification of the Tax System}

The complaint of Count Bentinck was the starting point of modern Dutch international tax policy. In the first place, the Ministry of Finance decided to make the Dutch income tax legislation more suitable for international tax policy. The Minister of Finance opened the fundamental discussion with Parliament by amending the pending proposal for the introduction of a Dutch (individual) income tax. The amendment consisted of the introduction of a statutory provision that would give the Government the mandate to conclude tax treaties. ${ }^{41}$ In the Government's explanation to this proposal, no reference was made to the

\footnotetext{
${ }^{36}$ According to the Wet op de Bedrijfsbelasting 1893, individuals resident in the Netherlands were nevertheless subject to a business tax on their worldwide business income, also see par. 2.2.3 below.

${ }^{37}$ Although Amsterdam is constitutionally the capital of the Netherlands, the seat of Government, parliament, the Supreme Court and the Council of State is in the city of The Hague (Den Haag).

${ }^{38}$ Letter of 5 May 1904, Netherlands National Archives (NL-HaNA), The Hague, file: Ministerie van Buitenlandse Zaken: A-files (hereafter NL-HaNA, BuZa / A-files), Access No. 2.05.03, Inventory No. 130.

${ }^{39}$ NL-HaNA, BuZa / A-files, 2.05.03, 130.

${ }^{40}$ At the time, a proposal from Minister of Finance De Meester for the introduction of a general income tax was still under debate in the Lower House.

${ }^{41}$ Article 123 of the proposed Individual Income Tax Act would then read: 'We reserve the right to conclude treaties with foreign Powers, which, in observance of the principle of reciprocity, that avoid or minimize the risk that income is subject to direct taxes - either directly or through the source from which they arise - both in this country as in the foreign country'. Also see Herndon, supra note 29, p. 14.
} 
complaint of the count, as the matter of double taxation was purely addressed as a matter of principle: 'the legislator cannot and should not be indifferent to this matter. It is a natural course, that the disadvantages of political borders are eliminated or reduced as far as possible and there is no reason why, in the effort in that direction, an exception should be made where it concerns taxation, ${ }^{32}$. Following this remark, the Minister of Finance referred to the above mentioned German 1870 Law and tax treaties signed since then. He stressed that the Netherlands should conclude similar treaties, as the absence of such arrangements could harm the open Dutch economy considerably.

The Minister of Finance decided expressly to work on reciprocal arrangements for the avoidance of double taxation, ${ }^{43}$ setting in motion the construction of the extensive Dutch tax treaty network. To support this policy, additional amendments were made to the Netherlands tax system. The most remarkable is the creation of double taxation aimed at avoiding double taxation. The Dutch legislator decided to extend the personal scope of the proposed income tax act, by subjecting non-residents to Netherlands income taxation on their immovable property in the Netherlands. ${ }^{44}$ In other words, the introduction of the non-resident's income tax liability was not only sparked by the desire to raise revenue, ${ }^{45}$ but also to increase the Dutch bargaining power in negotiations with other states. Or in the words of the Minister: 'to promote fruitful international tax policy..$^{46}$ Moreover, dividend taxation has a similar function in the eyes of the Dutch legislator. ${ }^{47}$ The Dutch legislator, however, has never gone so far as to introduce a withholding tax on interest, as sporadic proposals to introduce such a tax had led to severe resistance. Early proposals in the late $19^{\text {th }}$ century for the introduction of a general interest tax even lead to the resignation of the Minister of Finance. ${ }^{48}$ Legislative proposals for the introduction of an interest withholding tax in the 1930's and 1960's did not obtain majority support in the parliament. ${ }^{49}$

\subsubsection{World War I \& Conduit Policies}

While the Dutch legislator paved the way for a fruitful international tax policy, the talks between the Netherlands and Germany proceeded very slowly. By at the time the Netherlands Government had received its mandate to negotiate tax treaties through the Income Tax Act of 1914, World War I had broken out. Because of this war between the European superpowers, which strikingly again largely took place on Belgian territory, many European countries were forced to raise their taxes. The problem of double taxation

42 'Unilateral settlement of the subject is less advisable, since it is not certain or even probable that the foreign tax laws, to the interest of Dutch citizens, would be in line with the Dutch law, in the sense that both double taxation and useless lacunae were avoided. As long as not everywhere the same tax principles are applied, in general a good solution can only be reached by the way of concluding international agreements. That the principle of reciprocity should apply is not questionable and is also expressly stated in the proposed provision'; Kamerstukken II 1907/o8, No. 98, pp. 22-23, also cited in the first Memorandum General Treaty Policy, Kamerstukken II 1987/88, 20 365, No. 2, pp. 6-7.

${ }^{43}$ A few years later, the Dutch Government nevertheless decided to introduce unilateral measures for the avoidance of double taxation. In the first place, at the insistence of MP and former Minister De Meester measures were introduced for avoidance of double taxation in relation to subsidiaries of Dutch companies in the Dutch colonies and abroad, (Appendix of the Proceedings of the Lower House 1913/14, No. 18(3), documents 28 and 42), also see Jacques A.G. van der Geld, De Herziene Deelnemingsvrijstelling: Met Name in Internationale Verhoudingen, Deventer: Kluwer 2008, pp. 25-29.

${ }^{44}$ Response of the Government on questions from Parliament, Proceedings of the Lower House 1907/o8 No. 98, pp. 22-23. The proposed income tax was based on the ability to pay principle, which gave rise to income worldwide taxation, as income from anywhere in the world would attribute to an individual's ability to pay. Double taxation of cross-border income would interfere with the ability to pay principle.

${ }^{45}$ Ibid. The revenue loss resulting from giving up taxing rights under a tax treaty would primarily be covered by the introduction of a tax on non-resident's income from immovable property located in the Netherlands.

${ }^{46}$ Explanatory Note to the Proposed Law for the Imposition of an Income tax, Proceedings of the Lower House 1911/12, No. 144(3), p. 17. An earlier proposal for an income tax was never realized, but the later proposal incorporated many of the concepts and measures from the earlier proposal.

${ }^{47}$ For the same reason the Netherlands increased its dividend withholding tax rate from $15 \%$ to $25 \%$. In the eyes of the then State Secretary of Finance, this would improve the Dutch bargaining position in tax treaty negotiations; Kamerstukken II 1959/6o, 5380, No. 3, pp. 10-13, Kamerstukken II 1959/6o, 6ooo, No. 3, p. 26 (explanatory note).

${ }^{48}$ When Minister of Finance Vissering proposed to introduce a tax on interest payments in 188o (Draft legislation attached to Kamerstukken II 1879/188o, No. 127 (1)) he faced heavy criticism. As a result, he was even forced to step down, see parlement.com/id/vgoglljk47yf/s_vissering.

${ }^{49}$ In 1939, a proposal for a redesigned Income and Profit Tax Act contained a proposed tax on interest at a $2 \%$ rate. When the German occupying forces eventually introduced the Income and Profit Tax, this withholding tax on interest was not included. Finally, when in 1965 the Netherlands legislator revised the Dividend Tax Act, the suggestion from Members of Parliament to introduce an interest withholding tax was rejected expressly by the Government, Kamerstukken II 1965/66, No. 6 ooo (15) (final report). 
increased. Furthermore, the Dutch government decided to cash in on the fact that it remained neutral during the war. The Dutch government outlined the economic policy to position the Netherlands as a conduit between states that could not have direct economic relations during and shortly after the war. ${ }^{50}$ The absence of withholding taxes on interest supported the conduit policies.

In practice it however turned out to be impossible to hold bilateral or multilateral negotiations during and shortly after the war. In the absence of bilateral arrangements, the Dutch legislature decided to introduce several unilateral measures to avoid double taxation. ${ }^{51}$ These unilateral arrangements were generous and a significant departure from the concept of worldwide taxation. However, introduction of unilateral measures can be regarded as fitting in a trend that was set by the Dutch business tax law of 1893 that already included a generous double tax relief measure for profits made in the overseas territories..$^{52}$

\subsection{Actual Negotiations}

\subsubsection{Drafting of the Dutch-German Convention}

Behind the scenes, the Netherlands Ministry of Finance was nevertheless still actively engaged in the preparation of a treaty between the Netherlands and Germany. At the end of World War I, the Netherlands initiated (renewed) negotiations with Germany. In 1917 the negotiators exchanged the first draft treaties. ${ }^{53}$ In 1921, the heads of delegation ${ }^{54}$ Herbert Dorn ${ }^{55}$ (Germany) and Jan Sinninghe Damsté5 ${ }^{6}$ (the Netherlands) initialled a draft treaty in Berlin ${ }^{57}$. It must be noted that this is before the League of Nations released the first treaty models $\left(1927,{ }^{58} 1928^{59}\right)$ and even before seven technical experts published their report on the avoidance of double taxation in $1925^{60}$. The initialled draft treaty contained only a dozen articles. ${ }^{61}$ Starting point for the attribution of taxation rights was taxation in the resident state, ${ }^{62}$ but with some exceptions. In addition, in this text, no provision for administrative assistance was included. From the archives it appears

\footnotetext{
${ }^{50}$ Policies introduced in connection with the introduction of the Income Tax Act 1914, Explanatory Notes to The Foundations of the System of the National Taxes, Annex to Kamerstukken II 1915/16, No. 198(3), p. 17.

${ }^{51}$ In 1920 Article 101 was added to the Income Tax Act of 1914, mandating the Minister of Finance to introduce unilateral measures for the avoidance of double taxation for individuals to the extent treaties could not be invoked. In a Ministerial Resolution of 7 July 1920 the Minister used this mandate, see Government Gazette 1920, 131. In the years to follow several additional measures were introduced; see André H. Boekhoudt, De eenzijdige regeling - Het Besluit voorkoming dubbele belasting 1989, Deventer: Kluwer 2000, pp. 5-8.

${ }^{52}$ According to Article 37 of the said Act, an individual taxpayer deriving business profits from a colony was allowed as a deduction the tax that he would have to pay if his net income were equal to that which he derived from a given colony.

${ }^{53}$ Letter of the Minister of Finance to the Minister of Foreign Affairs of 8 February 1917, NL-HaNA, BuZa / A-files, No. 2.05.03, 130.

${ }^{54}$ The German delegation consisted of the gentlemen Pfeiffer and Dorn, while the gentlemen Sinninghe Damsté and De Vries were the Dutch delegates.

55 Dorn (1887-1957) was Director of Taxation for the Federal Ministry of Finance in pre-WWII Germany. Germany became Justice in the German Finanzhof, before the Nazi Government introduced legislation limiting the professional activities of persons with a Jewish background. Dorn, Jewish himself, fled to Cuba and later the USA via Switzerland before WWII started, see bundesfinanzministerium.de/Content/DE/Standardartikel/Ministerium/Geschaeftsbereich/Bundesfinanzakademie/Aktuelles/2012-03-27-geordnetefinanzen-herbert-dorn.html.

${ }^{56}$ According to the archived personnel records of the Netherlands Ministry of Finance, Sinninghe Damsté (1881-1960) worked for that ministry in the period 1904-1937; NL-HaNA, The Hague, Ministry of Finance, personnel records important persons, Access No. 2.08.83, Inventory No. 88. For a long term, he served as the Director-General of Taxation. From 1937 until 1951 Sinninghe Damsté was a justice at the Netherlands Supreme Court.

${ }^{57}$ The former Kingdom Württemberg joined the German Empire as the Freier Volksstaat Württemberg. The Imperial Law of 29 March 1920 introduced a income tax for the entire Empire, replacing the separate tax systems of the federal states.

${ }^{58}$ Committee of Technical Experts on Double Taxation and Tax Evasion, Double taxation and tax evasion, Geneva: League of Nations 1927 (G. 216 M. 85. 1927. II.1927.II.), p. 6. Sinninghe Damsté and Dorn were members of the Committee.

${ }^{59}$ Double taxation and Tax Evasion, Report presented by the General Meeting of Government Experts on Double Taxation and Tax Evasion, Geneva: League of Nations 1928 (Publications of the League of Nations 1928.II.49).

${ }^{60}$ At the insistence of the International Chamber of Commerce, the Financial Committee of the League of Nations invited a group of technical experts to give an opinion on the problem of double taxation and tax evasion. In 1925, seven experts including Sinninghe Damsté, issued a report. Other than the 1923 report of four economists, the technical experts mainly focused on finding practical solutions.

${ }^{61}$ From the archives it is not always clear which version of the treaty text was drafted at what stage. One of the draft texts that will be described below seems to have been initialed in 1921, and was probably attached to a memo of 17 August 1921 from the Netherlands Minister of Finance to the Economic Affairs Directorate of the Ministry of Foreign Affairs (Memo No. 1921/128).

${ }^{62}$ The draft text offered the possibility to solve double residence issues through a mutual agreement procedure.
} 
that the negotiators were planning to conclude a second convention covering administrative assistance, non-discrimination and most favoured nation treatment. However, as the Dutch and German tax officials already established in $1922,{ }^{63}$ the positions of the two countries diverted on many aspects of the treaty, meaning that final compromise could not be reached easily. Meanwhile, Dutch municipalities in the border region where knocking impatiently at the doors of the ministries in The Hague, complaining about the double taxation problems of the frontier workers. ${ }^{64}$ Although the Dutch ambassador in Berlin was sent off to find a solution to these problems, ${ }^{65}$ it appears that the Dutch efforts in this regard remained without results for a couple of years.

\subsubsection{Territorial Scope: Overseas Territories}

While these negotiations were effectively on hold, the Dutch governmental departments continued internal consultations to refine tax treaty policy. One item of discussion was the territorial scope of the future tax treaties. At the time, the Netherlands had overseas territories in the Caribbean and in current day Indonesia and Surinam. The departments of Finance, Foreign Affairs and Internal Affairs discussed about the position of these overseas territories to determine the territorial scope of the Kingdom's tax treaties. The Dutch governor in Batavia, current day Jakarta, strongly opposed to a territorial extension of the Dutch tax treaties to the Dutch Indies. ${ }^{66}$ Only in exceptional circumstances The Netherlands should consider to extend future tax treaties with Germany and other countries to the Dutch Indies. In contrast, the governorate in Paramaribo informed The Hague that extending the future tax arrangements to Surinam was desirable. ${ }^{67}$ Thus, in the draft treaty text, Netherlands and Germany agreed the territorial scope of the agreement to include 'the Netherlands in Europe and America'. ${ }^{68}$ Furthermore, the responsible Dutch Ministries also agreed that the material scope of the Netherlands tax treaty should also include taxes levied at municipal level. ${ }^{69}$

\subsubsection{Signature}

It was not until 1926 that the finalisation of the treaty picked up speed. In response to a letter from the Netherlands, the German Ministry of Finance sent an entirely new draft treaty text that seemed to be close to a compromise. This draft had a completely different structure than the earlier drafts, including arrangements for consultation and mutual assistance between the tax authorities. Germany felt that on the basis of this new draft a treaty could soon be signed and urged for speed. Despite this insisting on the German side, the Netherlands did not provide the Dutch ambassador an authorization for signature until early $1928 .{ }^{7}$ On 24 August 1928, the Netherlands embassy in Berlin informed The Hague by telegram:

“TREATY SIGNED TODAY GOVERNMENT GAVE SHORT PRESS STATEMENT". ${ }^{71}$

\footnotetext{
${ }^{63}$ Letter of the Netherlands Ministry of Foreign Affairs to the Netherlands ambassador in Berlin of 28 October 1922, NL-HaNA, BuZa / A-files, No. $2.05 \cdot 37 / 2714$.

${ }^{64}$ The Mayor and Executive Board of the border town of Dinxperloo requested the Minister of Employment to make preliminary arrangement for crossborder workers pending the negotiations of a treaty; Letter of the College of 14 September 1922 to the Netherlands Minister of Employment, NL-HaNA, BuZa / A-files, No. 2.05.37/2714.

${ }^{65}$ Letter from the Ministry of Foreign Affairs to the Ministry of Employment of 29 October 1922, NL-HaNA, BuZa / A-files, No. 2.05.37/2714.

${ }^{66}$ Letter from the Colonial Government in Batavia (Jakarta, Indonesia) of 12 May 1922, NL-HaNA, BuZa / A-files, No. 2.05.37/2714.

${ }^{67}$ Letter from the Colonial Government in Paramaribo (Suriname) of 27 December 1921, NL-HaNA, BuZa / A-files, No. 2.05.37, 2714.

68 'Deses Uebereinkommen findet einerseits Anwendung auf Das Deutsche Reich und anderseits auf die in Europa und Amerika belegenen Teile des Königsreichs der Niederlanden', ('This Convention shall apply on the one hand to the German Empire and on the other hand to in the parts of the Kingdom of the Netherlands situated in Europe and America'); letter from the Ministry of Foreign Affairs to the Ministry of Finance of 2 June 1922 , NL-HaNA, BuZa / Afiles, No. 2.05·37, 2714 .

${ }^{69}$ Later reaffirmed by letter from the Ministry of Finance to the Ministry of Foreign Affairs, No. 95, 1927, referring to correspondence with the Ministry of Internal Affairs and Agriculture, NL-HaNA, BuZa / A-files, No. 2.05.37, 2714.

${ }^{70}$ Letter from the Ministry of Foreign Affairs to the Netherlands embassy in Berlin of 5 April 1928, NL-HaNA, BuZa / A-files, No. 2.05.37, 2714.

${ }^{71}$ Telegram received on 24 August 1928, NL-HaNA, BuZa / A-files, No. 2.05.37, 2714.
} 


\subsection{Ratification}

As a result of the press statement of the signing ceremony and the subsequent reports in the newspapers, the general public was curious. Unlike nowadays, the contents of the treaty still had not been made public at the day of signature. The treaty text would remain secret until the text was presented to parliament as part of the ratification process. The Netherlands government informed Germany that it was positive about the ratification process and expected to be able to present the treaty to the Netherlands parliament soon. First, however, some time was needed to obtain approval from the Netherlands Council of State.

The public's curiosity got heightened when the newspapers reported on some statements made by Sinninghe Damsté about the content of treaty, en marge of the League of Nations Assembly in Geneva. His statements caused a shock wave through the Dutch business community, as Sinninghe Damsté had revealed that the treaty contained a provision on tax information exchange. The business community complained that they had had no say in the development of the treaty, in the same way as they felt they were too little consulted on the League of Nations' activities. In their own periodical they complained:

'In the preparations of the participation in the Conference, the Government refrained from keeping in touch with the bodies of industry. In Geneva, the Dutch delegate made questionable statements.

As our readers have learned from the papers, a Conference on the avoidance of double taxation and tax evasion took place in Geneva last week, where 28 states were represented by Government Experts (...) We only want to draw attention to some statements made by the Netherlands delegate, Mr. Dr. Sinninghe Damsté, during the Conference which surprised us very much.

In itself it seems exceedingly strange to us that we could only learn these statements

from the papers.

In Government circles they should know the address of our Association or of the Industry Council by now! (....)

Furthermore, except the Government nobody in the Netherlands, nor even the parliamentarians, knew something of this treaty. (...) Further on, we learned that Mr. Sinninghe Damste declared, amongst others, that the Netherlands would preserve its bank secrecy and that such should not be considered as hostility towards foreign states, as this is the logical consequence of the principle of equal treatment.

(...) The Netherlands Government is always willing to provide foreign authorities with information, coming from the accounts of the taxpayers. ${ }^{172}$

At the same time the Council of State was working on its advisory report to the Queen regarding the draft bill of ratification for the treaty. The Council sent its report to Government on 12 February 1929. The Council of State supported the general scope of the treaty, and it had only a few minor remarks and questions regarding the technical elements of the convention. ${ }^{73}$ However, the Council expressed serious concerns on how the treaty came into being and what outcome was reached regarding mutual assistance:

'Article 14, paragraph 1, of the agreement, gives rise to detailed analysis. This provision may in itself be considered innocent, or seem at least little dangerous. In the case where it is intended to be applied to complex situations, the peculiarities of which it takes not into account, it can be foreseen that it will cause serious damage. The facts are these: on the one hand the Dutch money market is entrusted with giant capital by foreign (mostly German) clients, especially because they are assured absolute confidentiality in respect of the deposits they have made in this country; on the other hand, the conclusion of the above treaty provision will destroy this assurance.'

\footnotetext{
${ }^{72}$ De Nederlandsche Werkgever, No. 1928, 44, p. 1.

${ }^{73}$ Opinion of the Council of State of 12 February 1921, No. 31, NL-HaNA, BuZa / A-files, No. 2.05.37, 2715. The Council particularly wondered how to allocate the profits between a foreign permanent establishment and the domestic headquarters.
} 
The Council of State spoke in superlatives about this provision, that '(...) had aroused deep emotions in the circles of the Dutch money markets, and that the further course of this case will be followed with great concern, (...)'.

The Council of State therefore rejected the treaty and advised not to present the treaty to parliament for ratification. Effectively the Council of State requested renegotiations, this time with involvement of the business community. With this advice, the Council of State laid the foundation for the common practice for the continuous consultation of stakeholders in the development of tax treaties. ${ }^{74}$ In current treaty practice, the Netherlands Ministry of Finance announces periodically with which states the Netherlands envisages to start negotiations with. ${ }^{75}$

The Dutch position on exchange of information in tax matters is remarkable, especially in light of the Dutch involvement in the battle against bank secrecy in recent years. ${ }^{76}$ In 1928 the ratification of the first real Dutch tax treaty was upheld as the Netherlands decided to hold on to its bank secrecy. Dutch banks had earned a lot from the capital flight from Germany, Italy and France during and after WWI. Many MPs were also very hesitant about information exchange with other states, worrying about the treatment of that information by foreign authorities. ${ }^{77}$ Other MPs were more willing to exchange information in tax matters. ${ }^{78}$ The Dutch Government preferred to remain silent on bank secrecy. Only a few years later in the context of the continuing parliamentary discussion on bank secrecy the Government stated with telegraphic brevity: 'Even in the opinion of the Experts of the League, abolition of bank secrecy in favour of the tax authorities is out of the question because of the great economic interests at stake. ${ }^{79}$

From the consulted files held by the Netherlands National Archives, it clearly arises that the bilateral tax relations with Germany were actually a personal project of Sinninghe Damsté. ${ }^{80}$ It had turned out that it had been a big risk for the Dutch Minister of Finance to put the negotiations in the hands of Sinninghe Damsté. The Ministry of Foreign Affairs had already warned for the solitary actions of Sinninghe Damsté, ${ }^{81}$ who was later commemorated as being very authoritarian. ${ }^{82}$ In any case, Sinninghe Damsté had played a key role in the conception of early Dutch tax treaty policy. And his influence reached beyond his country's borders. Sinninghe Damsté had practical experiences as tax treaty negotiators before he and his German opponent Dorn became member to the League of Nations expert committees, meaning that the experience with tax treaty negotiations were decisive for the development of the League's tax treaty models. This sheds a different light on the influence of the work of the League of Nations committees and their successors on

\footnotetext{
${ }^{74}$ As the Council of State put it: 'Without prejudice to the skills of the civil servants who tend to be charged with this task of preparation, it may nevertheless be assumed that the practical consequences of such a treaty for trade, industry and the banking sector can best be foreseen by experts in this area; or, in any case, the information of these experts can be of great significance for these government officials'.

75 'Onderhandelingen in 2013' (Negotiations in 2012), news report of the Ministry of Finance of 24 April 2013, overheid.nl. The Ministry also invited stakeholders to contribute to the Government's 2011 Tax Treaty Memorandum, see 'Ministerie van Financiën start Consultatie Fiscaal Verdragsbeleid' (Ministry of Finance Initiates Tax Treaty Consultations), news report of the Ministry of Finance of 31 Augustus 20o9, overheid.nl.

${ }^{76}$ This means that the Netherlands had a similar bank secrecy policy as Switzerland, Liechtenstein, Luxembourg and Belgium. See for a comparison of the comparison of the bank secrecy policies at that time: Robert U. Vogler, Das Schweizer Bankgeheimnis: Enstehung, Bedeutung, Mythos, Zürich: Verein Für Finanzgeschichte 2005, pp. 56-61.

${ }^{77}$ MP Van Grijn, amongst others, expressed these concerns and added that he was irritated by the fact that the 1928 treaty text had still not been submitted to parliament; Session of 12 December 1928, Proceedings of the Lower House 1928/29, p. 987.

${ }^{78}$ Preliminary Proceedings of the General Debate, Kamerstukken II 1932/33, No. 2 VII B. 6, Annex A, p. 1.

79 In the course of time several members of the League of Nations have called for attention to the prevention of 'tax fraud', such as France; Kamerstukken II 1936/37, No. 2., III. 7, Annex A, p. 23.

${ }^{80}$ Sinninghe Damsté was also commemorated as a language virtuoso and admirer of German literature, which helps to explain his predilection for the Dutch-German negotiations and his activities for the League of Nations; J. Van der Poel, 'Mr. Dr. J.H.R. Sinninghe Damsté 75 jaar', Weekblad Fiscaal Recht 1956/4322, p. 882, cited by Peter Essers, Belast Verleden - Het Nederlands belastingrecht onder nationaalsocialistisch regime, Deventer: Kluwer 2012, p. 6465.

${ }^{81}$ Within the Ministry of Foreign Affairs this matter had already been discussed. On 23 February 1927 the Legal Affairs Directorate wrote to the Economic Affairs department that the Ministry of Foreign Affairs should monitor the treaty negotiations, as the treaty was negotiated mainly one on one by Sinninghe Damsté, risking that the Ministry of Finance would be insufficiently critical of its own work. Furthermore the Legal Affairs Directorate concluded that it was not required to submit the treaty with Germany to the parliament for approval.

${ }^{82}$ Cited by Peter Essers, supra note 8o, p. 64-65.
} 
the development of international tax law. International organizations that are involved in international tax matters are not autonomously developing international policy, but are to are large extent forums where knowledge and experience of key people come together and is consolidated to be conveyed to a wider audience.

\subsection{Renegotations and New Ratification}

The Council of State had effectively forced the Dutch Government to get back to Berlin. The Dutch Ministry of Finance requested the deletion of the challenged Article 14 of the 1928 treaty. The discussion did not progress at rapid pace. Meanwhile, the Dutch banking sector became more nervous by the day. ${ }^{83}$ At the suggestion of the Germans, the negotiators first explored the option of concluding a protocol to the 1928 treaty. ${ }^{84}$ When in 1931 a compromise seemed to have been reached, the German Ministry of Finance concluded that this compromise could not count on a majority in the German Bundestag. As an alternative solution to counter at least some of the still occurring double taxation, Berlin suggested to conclude a more general Rahmenverdrag. ${ }^{85}$ This brief, general agreement for the avoidance of double taxation was however not concluded. The Dutch probably held on to their preference to conclude a full tax treaty, while the Germans were not willing to renegotiate the full treaty. The negotiation process came to a standstill. From the Dutch archives it appears that the Dutch and German finance officials had no formal contact for a couple of years. While the negotiations were upheld, the stacks of complaint letters from citizens and business were growing on the desks of the officials in the Netherlands Ministries. When the Netherlands government learned from the newspapers that Germany and Switzerland were conducting treaty negotiations in 1933, The Hague assigned the ambassador in Berlin to inquire whether the Dutch-German negotiation process could now be back on track. The ambassador learned that this would not be the case. He informed the Netherlands Ministries of Foreign Affairs and Finance: 'A major drawback was that this matter was previously dealt with by the Minister of Finance, and that the current official did not understand these matters. ${ }^{86}$ It was decided to set the matter aside for the moment.

Within a year, in 1934, the treaty negotiations were nevertheless reopened. Remarkably, the 1928 treaty was adjusted with minimal concessions from Germany. The challenged provision on administrative assistance remained largely intact. The main difference was that the provision was drafted in more detail. On May 13, 1937, a revamped version of the 1928 treaty was signed, just two weeks before parliamentary elections were held in the Netherlands.

The 1937 treaty was also not revealed at signing. And just as the 1928 treaty, this treaty stranded on a negative opinion of the Council of State. The Council of State observed that the treaty materially differed little from the 1928 treaty, so the main concerns remained valid. Meanwhile, the liberals (Liberale Staatspartij) who had presumably pushed for a treaty for the avoidance of double taxation had not returned to Government after the general elections in the summer of 1937. The Ministers of the new Government decided to follow the opinion of the Council of State, by deciding once more to withdraw the bill for the approval of the treaty.

\footnotetext{
${ }^{83}$ The German clients of the banks were frightened by reports in the German newspapers, such as 'Achtung, ein Pakt gegen Steuerflucht! Deutschlands und Hollands Steuerbehörden beabsichtigen "Auslieferungsvertrag”, ('Attention, a Pact Against tax Evasion! Germany and Holland Tax Authorities Intend "Extradition Treaty"), Berliner 12 uhr Zeitung, 28 March 1930, p. 2.

${ }^{84}$ Letter from the Netherlands ambassador in Berlin to the Netherlands Minister of Foreign of 13 September 1930, NL-HaNA, BuZa / A-files, No. 2.05.37, 2715 .

${ }^{85}$ According to the Netherlands' ambassador in Berlin in his letter to the Netherlands Minister of Foreign Affairs of 14 February 1931, NL-HaNA, BuZa / Afiles, No. 2.05.37, 2715 .

${ }^{86}$ Letter from the Netherlands' ambassador in Berlin to the Minister of Foreign Affairs of 7 June 1932. Count Bentinck, among others, referred to news coverage in the German and Swiss press, such as Neue Züricher Zeitung, 22 January 1932, p. 2; letter from L.A. Ruys on behalf of Count Bentinck of 11 February 1932, NL-HaNA, BuZa / A-files, No. 2.05.37, 2715,
} 
More than three decades after the complaint of Count Bentinck still no tax treaty was concluded between the Netherlands and its main trading partner. Through the steward of his estate Middachten, Count Bentinck informed the Minister of Finance that he was sad to read the statement of the Governmental Press Office of the withdrawal of the bill of ratification ${ }^{87}$ He again complained that he would like nothing better than to live at Middachten full time, which he could not afford as a result of the double taxation. ${ }^{88}$ Also the many cross-border workers and entrepreneurs in the border region remained deprived of a tax treaty.

Also in relation to other countries, citizens and entrepreneurs had to wait a long time before tax treaties saw the light of day. In the interbellum the Netherlands managed to conclude only a handful of tax treaties, despite the Netherlands' commitment to the League of Nations tax committees. ${ }^{89}$ The first overall tax treaty that entered into force was a treaty with Belgium (1933). ${ }^{90}$ This first overall tax treaty was part of a package of trade related treaties. ${ }^{91}$ In addition, the Netherlands concluded treaties with Sweden (1935), the United Kingdom (1935) and Hungary (1938).

It was long after WWII that the Netherlands concluded a tax treaty with its main trading partner. The relationship regarding tax matters between the two countries remained troubled in the years to come. It would take until 1958 before a tax treaty could be concluded and ratified. ${ }^{92}$ At that time, bank secrecy was not an issue anymore, after the German occupier had slashed Dutch bank secrecy in $1941 .{ }^{93}$ Germany and the Netherlands had nevertheless many more issues to resolve. Issues that fall beyond the scope of this contribution on early Dutch tax treaty policy. Also taking into account that it took another five decades before the Netherlands and Germany signed a new tax treaty in $2012,{ }^{94}$ it is clear that treaty negotiation between neighbouring countries often follow an erratic course.

\section{Conclusion}

The roots of the current Dutch tax treaty policy lay in the political and economic developments in Europe in the $19^{\text {th }}$ century. The early treaties in the field of tax law are a product of the chess games between the European powers that partly took place on the territory of the Benelux. Contending European states developed sophisticated strategies for the negotiations of tax treaties. Such was uncovered by economic research on the formation of the Zollverein and was illustrated by the anecdotal evidence on how the Zollverein members played the Netherlands off against Belgium. Understanding these strategies can help to understand which negotiation strategies are applied by countries in their tax treaty policies. Economic integration of the German states necessitated finding legal solutions to problems in areas such as double taxation. In the context of economic and political integration the basic instruments were developed that are

\footnotetext{
${ }^{87}$ Letter from steward L.A. Ruys to the Minister of Finance of 16 March 1938, NL-HaNA, BuZa / A-dossiers, 2.05.03, 2716.

${ }^{88}$ In 1929 Bentinck decided to move to Germany permanently. By avoiding staying for more than 90 days in the Netherlands, he was not regarded as a resident of the Netherlands anymore, ending the double residency. In 2011, Bentinck's daughter received an award from the Prince Bernhard Cultural Fund for for her altruistic dedication to the restoration and preservation of the Middachten estate. On the occasion of the award ceremony she commemorated: 'In 1929 we had to close down due to the taxes, otherwise it would have been too expensive'; video via Youtube, see etld.blogspot.com.

${ }^{89}$ In fact, the annual number of tax treaties concluded between League of Nation member states decreased during the decade following the publication of the model treaties, also see Spitaler, supra note 3, p. 31.

$9^{\circ}$ Treaty of 20 February 1933 . Both parties had already intended to conclude a treaty since 1920.

${ }^{91}$ Letter of the Minister of Foreign Affairs to the Minister of Finance of 16 January 1932, No. DEZ 32/1802; W.J.M. Klaassen, J. Woltring \& W.F. Renaud (eds.), Documenten betreffende de Buitenlandse politiek van Nederland 1931-1945 - Periode B 1931-1940, Part I, The Hague: Martinus Nijhoff 1985, pp. 561564 .

${ }^{22}$ Treaty of 18 August 1958 between the Bundesrepublik Deutschland and the Netherlands. However, before ratification, this treaty was amended, resulting in a new treaty of 16 June 1959. This treaty was entered into force in 1960, but it had retroactive effect, as upon entry into force the treaty became effective on 1 January 1956 (1958 for dividends), and therefore often is incorrectly referred to as the 1956 tax treaty.

${ }^{93}$ See Peter Essers, supra note 8o, pp. 172-173. On 28 August 1941, the occupying government issued a Decree for the avoidance of double taxation in relation to the German Empire, Staatsblad No. 426. Article 3 of the Decree required the Dutch tax administration to offer administrative assistance in tax matters to the German Empire.

${ }^{94}$ Treaty of 12 April 2012.
} 
now core elements of contemporary treaties for the avoidance of double taxation. This was true for cooperation within the German Confederation and the subsequent North German Confederation (PrussiaSaxony tax treaty 1869 , the 1870 Law), but also within the tripartite alliance (Prussia-Austria-Hungary treaty 1899). In turn, these arrangements for the avoidance of double taxation helped shaping the composition of contemporary income tax systems.

The Netherlands started building its extensive tax treaty network only at the beginning of the twentieth century. In contrast with what Dutch legislative history suggests, the tax treaty negotiations were not sparked by fundamental, macro-economic considerations. Archival research has uncovered that it was sparked by a complaint of an influential nobleman. For the purpose of a fruitful policy on concluding treaties for the avoidance of double taxation, double taxation was created: the paradox of double taxation. And even long before the Netherlands signed its first tax treaty, it had established a policy to become an intermediate state for trade and investment income. This policy, however, was unsuccessful at the beginning. Despite the initial intentions to only provide for relief of double taxation on the basis of reciprocity, later the Dutch legislator reluctantly had to introduce unilateral measures. As the Dutch international tax policy was developed in parallel with the income tax system, the Dutch income tax system was shaped by tax treaty law, following the pattern that also occurred in the German states in the preceding decades.

Meanwhile, the experience of key persons like Sinninghe Damsté and Dorn had a significant impact on the work of the League of Nations. Their practical experience tax treaty negotiations were decisive for the development of the League's tax treaty models. This sheds a different light on the influence of the work of the League of Nations committees and their successors on the development of international tax law. International organizations that are involved in international tax matters are not autonomously developing international policy, but are rather forums where knowledge and experience of key people come together and is consolidated to be conveyed to a wider audience.

Dependence on key persons may however take its toll. The solitary action of Sinninghe Damsté turned out to be a big risk for the Netherlands when it became clear that the agreed mutual assistance provision was unacceptable to the Dutch business community. As a result, the 1928 tax treaty was not ratified. The Netherlands Council of State forced that from that moment on the Dutch tax treaty negotiators were required to consult the stakeholders, marking the start of the close cooperation between the Dutch tax treaty negotiators and the business community. The desire of the business community and the majority of the politicians to maintain the Dutch bank secrecy had no foothold in Germany. Powerful Germany did not agree to drop the mutual assistance provision. A renewed effort to ratify a revamped version of the 1928 treaty stranded in late thirties. Only in the fifties, Germany and the Netherlands successfully concluded a new tax treaty.

The development of treaty policy depends on many factors. On the one hand, the chess-games between superpowers limit the fiscal autonomy of the neighboring states, including in the field of tax treaties. Tax treaties in turn influence the design of the national tax systems. On the other hand, certain individuals can play a key role in the development of treaty policy. These effects are usually not obvious at first glance, but reconstructions contained in this article can help to identify the determinants of tax treaty policy. With this knowledge, a tax expert can consider a tax treaty in its context, realizing a treaty is not a collection of rules that came falling out of blue skies. 